\title{
DINAMIKA RELASI SOSIAL-KEAGAMAAN MASYARAKAT AHMADIYAH DAN NON-AHMADIYAH'
}

\section{THE DYNAMICS OF SOCIALRELIGIOUS RELATIONSHIP BETWEEN INDONESIAN AHMADIYYA COMMUNITY AND NON-AHMADIYYA COMMUNITY}

\author{
Mardian Sulistyati \\ Institute of Southeast Asian Islam (ISAIs) UIN Sunan Kalijaga Yogyakarta \\ dianmakruf@gmail.com
}

\begin{abstract}
Religious sentiment is often called as primary factor behind the many cases of violent conflict in Indonesia. Nevertheless, many contemporary studies on conflict and peace showed that trigger variables of conflict are not only varied but also layered and unique. This article reveals about the relational model and management between JAI (Jemaat Ahmadiyah Indonesia/Indonesian Ahmadiyya Community) and non-JAI in the rural Manislor. By phenomenology, this study looked at the depth of relations, perceptions, and conceptions of both groups; and by genetic structuralism of Bourdieu, this study revealed the relationships that unite and integrate of these two groups. Some of the findings appeared that besides the theological factor, the variables such as group sentiments, space separation, identity polemic, economical jealousy, political jealousy and elite interference, contribute to the segregation and conflict between them. Thus, this is the the strengthening of social bonding such as local habituations and local wisdoms is an urgent matter to build a suistainable peace. As well as the agents of civil society, with their own way, must be readily to care and control the mechanisms of conflict resolution.
\end{abstract}

Keywords: socialreligious relationship, segregation, bonds of citizenship, Jemaat Ahmadiyah Indonesia, manislor.

\begin{abstract}
Abstrak
Dalam berbagai kasus konflik kekerasan yang marak terjadi di Indonesia, sentimen agama sering dikatakan sebagai faktor utama dibaliknya. Namun demikian, studi-studi kontemporer atas konflik dan perdamaian, menunjukkan bahwa variabel yang menjadi pemicu konflik bukan saja beragam, tetapi juga berlapis dan unik. Tulisan ini mengkaji model relasi dan pengelolaan relasional antarkelompok beragama JAI dan non-JAI di Permukiman Desa Manislor. Dengan menggunakan kaca mata fenomenologi, penelitian ini melihat kedalaman relasi, persepsi, dan konsepsi kedua kelompok; serta dengan sudut pandang strukturalisme genetik Bourdieu, penelitian ini mengungkap relasi kedua kelompok yang bersifat menyatukan dan mengintegrasi di tengah tarikmenarik situasi kultural dan kekuasaan yang melingkupinya. Hasil penelitian menunjukkan bahwa faktor-faktor sepertisentimen kelompok, pemisahan ruang, polemik identitas, kecemburuan ekonomi, kecemburuan politik, hingga interfensi elit, turut menyumbang segregasi konflik antara masyarakat JAI dan non-JAI di Manislor, di samping faktor teologis. Namun demikian, pada saat bersamaan penelitian ini juga menguak faktor-faktor kultural-tradisi yang justru memperkuat ikatan kewargaan antarkelompok, bahkan ketika dalam keadaan bertikai sekalipun. Pada akhirnya, penelitian ini menemukan urgensitasnya: pengarus utama anhabituasi-habituasi lokal sebagai resolusi konflik dalam upaya membangun binadamai nirkekerasan. Begitu pula agen-agen civil society yang dengan caranya masing-masing, merupakan potensi penting dalam pengembangan mekanisme penanganan konflik.
\end{abstract}

Kata kunci: relasi sosial-keagamaan, segregasi, ikatan kewargaan, jemaat Ahmadiyah Indonesia, manislor.

${ }^{1}$ Penelitian ini difasilitasi oleh Institute of Southeast Asian Islam (ISAIs) Universitas Islam Negeri Sunan Kalijaga, dan hasil penelitiannya pernah didiseminasikan melalui/di ISAIs pada 12 November 2015 di Yogyakarta. Satu tahun berikutnya, diseminarkan dalam Seminar Internasional "Islam and Democracy; In Search of Democratic Models in Muslim Countriest" pada 16-17 November 2016 di Sekolah Pascasarjana Universitas Islam Negeri Syarif Hidayatullah Jakarta. 


\section{Pengantar}

"Social conflict and social integration must not be seen as opposites but as different sides of the same coin."(Roberts, 2004: 60)

Tidak bisa diabaikan, sentimen agama telah dan masih menjadi pemantik paling efektif lahirnya konflik bernuansa kekerasan/violent conflicts yang marak terjadi di Indonesia dalam bentang dua dekade terakhir (Maso'ed \& Maksum, 2000; Bertrand, 2007; Mujiburrahman, 2006; Mclaughlin \& Perdana, 2010). The Wahid Institute menjabarkan, angka kekerasan/ pelanggaran kebebasan beragama/ berkeyakinan dari tahun ke tahun yang berlangsung flukuatif: 121 peristiwa pada tahun 2009,184 peristiwa pada tahun 2010, 267 peristiwa pada tahun 2011, 278 peristiwa pada tahun 2012, 245 peristiwa pada tahun 2013, dan 158 peristiwa pada tahun 2014 (Wahid Institute, 2014: 21-29; Peace \& Risk, 2014). Kemudian pada tahun 2015, SETARA Institute mencatat 188 peristiwa kekerasan/pelanggaran kebebasan beragama/ berkeyakinan dengan 224 bentuk tindakan (SETARA Institute, 2016). Laporan terbaru yakni sepanjang tahun 2016, angka tersebut meningkat signifikan menjadi 208 peristiwa dengan 270 bentuk tindakan yang tersebar di 24 provinsi di Indonesia (SETARA Institute, 2017).

Meski secara ideal-normatif tidak ada agama yang memimpikan konflik, namun secara faktual-historis hubungan antarkelompok beragama kerap diwarnai ketegangan/presence of tension dan perselisihan/disagreement (Colbran, 2016; Amstrong, 2013: 10). Tidak hanya di Indonesia, konflik-konflik tak berkesudahan atas nama agama juga terjadi di orbit bumi yang lain seperti konflik Yahudi-Muslim di Palestina, Buddhis-Hindu di Srilangka, Hindu-Muslim di India, Muslim-Kristen di Nigeria Barat, Judeo Kristen-Muslim Ekstrimis, dan ragam kasus lainnya. Tak heran bila pada akhirnya Vendley (2011: 698) menyebut-nyebut konflik kekerasan bersinonim dengan konflik agama. Namun tentu layak untuk dipertanyakan ulang apakah agama benar-benar menjadi indikator utama atas munculnya konflik dan menguatnya intoleransi dalam relasi kemasyarakatan kita.

Agaknya kita harus mengakui bahwa model relasi sosial dalam masyarakat dewasa ini sedikit banyak bersifat mensegregasi dan mengisolasi: membuat satu kelompok berdasarkan satu kesamaan tertentu di dalam suatu permukiman masyarakat.Model yang secara teoretis bersifat acuh/indiferensi memang terbentuk hampir di tiap hubungan antar-etnik, suku, dan tentu saja agama.Secara historis, pola pemisahan memang pernah sengaja diadopsi oleh Pemerintah Orde Baru sebagai bagian dari politik relasi untuk mengeliminir kemungkinan terjadinya konflik antarkelompok. Upaya ini menjadi bagian integral dari preservasi SARA yang mana negara dengan sistematis menjadikan isu suku, agama, ras, dan antargolongan tabu untuk diperbincangkan di ruang publik (Ropi, 2012). Namun sisi lainnya, masyarakat dengan pola relasi ini terlanjur betah dalam zona nyaman wilayah masing-masing. Masyarakat menjadi kurang siap untuk melihat atau menghargai perbedaan secara alami; tidak luwes dalam diferensi (Kymlicka, 2001: 304). Konsekuensinya, ada nilai-nilai kewargaan/civic values dan keadaban/culture values yang tereduksi. Pada level tertentu, pola ini menciptakan enklaf-enklaf baru yang pada akhirnya membuka jalan bagi segregasi lanjutan.

Salah satu fenomena yang menarik untuk dikaji terkait model relasi dan pengelolaanrelasional antarkelompok beragama adalah Jemaat Ahmadiyah Indonesia (JAI) dengan non-JAI di Permukiman Desa Manislor. Alasannya, keberadaan Jemaat Ahmadiyah dan Non-Jemaat Ahmadiyah di Desa Manislor tergolong unik jika dilihat dari segi kuantitas. Jemaat Ahmadiyah yang notabene kelompok minoritas - dalam lanskap Islam Indonesia, di Desa Manislor justru terbilang dominan yakni tidak kurang dari tujuh puluh persen dari total keseluruhan pemukim (YA., wawancara mendalam, 25 Oktober, 2015). Maka tidak berlebihan jika dalam konteks Desa Manislor, kelompok masyarakat Jemaat Ahmadiyah penulis sebut sebagai kelompok "minoritas yang mayor". Pun sebaliknya bagi kelompok masyarakat Non-Jemaat Ahmadiyah; "mayoritas yang minor" dalam konteks Desa Manislor.

Terhadap lokus pola relasional dua kelompok tersebut, penulis melakukan pengkajian secara utuh dengan mengungkap dua hal sekaligus: potensi konflik dan potensi damai; segregasi dan integrasi. Artinya, penelitian ini tidak hanya berfokus kepada konflik kekerasan, tetapi juga secara imbang berfokus kepada potensi integrasi antarkelompok tersebut. Penelitian berimbang ini menjadi penting dilakukan dalam upaya menampilkan wawasan yang juga berimbang, baik di kalangan 
akademis maupun umum, bahwa artikulasi konflik keagamaan yang terjadi sejatinya tidak hanya tersalurkan melalui cara-cara kekerasan, melainkan juga dalam bentuk aksi damai.

Guna menganalisis model relasi dan pengelolaan relasional antaraJemaat Ahmadiyah dan Non-Jemaat Ahmadiyah di Desa Manislor, penulis merangkul beberapa teori besar yang relevan. Pertama, untuk membaca sebab/faktor terjadinya konflik/segregasi, penulis mengadopsi teori hubungan masyarakat dan teori transformasi konflik. Teori hubungan masyarakat menyatakan bahwa konflik terjadi disebabkan oleh polarisasi yang terus terjadi, ketidakpercayaan, dan permusuhan antarkelompok yang berbeda. Sedangkan teori transformasi konflik mengindikasikan ketidaksetaraan dan ketidakadilan yang muncul dalam tataran sosial, budaya, dan ekonomi sebagai penyebab dominan terjadinya konflik(Fisher et al., 2000: 4-5).Kedua, untuk membaca potensi dan pola penyatuan/integrasi kedua kelompok, penulis mengadopsi duateori modal sosial: (1) Modal sosial yang bersifat penguatan internal kelompok atau yang dikenal dengan istilah bonding; dan (2) Modal sosial yang bersifat ikatan kewargaan yang terjalin antarkelompok atau yang dikenal dengan istilah bridging (Putnam, Leonardi, \& Nanetti, 1993: 167; Colemen, 1990).Kedua modal sosial ini dalam konsep Ashutosh Varshney dikenal dengan istilah intracommunal dan intercommunal engagement(Patulny, Lind, \& Svendsen, 2007).

Dengan beberapa modifikasi, dua pendekatan penulisgabungkan dalam proses membaca lokus penelitian ini: pendekatan fenomenologi dengan metode epoche dan eidetich vision(Erricker, 2002: 110-111; King, 1995; Adams, 1985: 143) dan pendekatan strukturalisme genetik Bourdieu (Vandenberghe, 2006;Barker, 2004: 16; Bourdieu \& Wacquant, 1992: 18). Pendekatan fenomenologi efektif untuk mendalami relasi, persepsi, dan konsepsidari kelompok Jemaat Ahmadiyah terhadap Non-Jemaat Ahmadiyahpun sebaliknya. Sedangkan pendekatan strukturalisme genetik penulis gunakan untuk mengungkap relasi kedua kelompokyang bersifat menyatukan dan mengintegrasi; yang berhadapan dengan opresi sistem kultural dan dominasi kekuasaantermasuk faktor luaran seperti peran lembaga negara dan organisasi kemasyarakatan dan/atau keagamaan non-negara.Struktruralisme genetik bekerja dengan menjembatani antara dikotomi pelaku dan struktur sosial, kebebasan dan determinisme, pengkondisian dan kreativitas, serta kesadaran dan ketidaksadaran. Meski pendekatan ini pertama kali digunakan oleh Bourdieu untuk membaca karya sastra, namun dengan beberapa modifikasi, penulis melihat relevansinya untuk digunakan di dalam penelitian ini. Selanjutnya untuk tahapan dan teknik analisis data, penulis mengadopsi prosedur analisis yang dipelopori oleh Miles, Huberman, \& Saldana(2014), yaitu reduksi data, penyajian data, dan penarikan simpulan.

\section{Ikatan Kewargaan Manislor dalam Kultur Manusia Kuningan}

Berada tepat di pertengahan jalan raya yang menghubungkan Cirebon dan Kuningan, Desa Manislor terbilang sangat strategis dan padat. Terlebih, desa ini menjadi bagian dari Kabupaten Kuningan yang memiliki peran vital penghubung wilayah Priangan Timur dengan Cirebon dan Jawa Tengah. Dengan luas wilayah $123 \mathrm{Ha}$., desa yang kurang lebih $4 \mathrm{~km}$. dari kaki Gunung Ciremai ini terdiri dari tanah permukiman dan persawahan. Berdasarkan catatan Badan Pusat Statistik Kabupaten Kuningan (2016: 14), jumlah penduduk yang bermukim di Desa Manislor terdata sebanyak 4.616 jiwa. Tidak ada catatan mengenai angka pasti jumlah JAI di desa ini, namun beberapa narasumber menyebutkan bahwa jumlah Jemaat Ahmadiyah di Desa Manislor tidak kurang dari 3.000 jiwa atau sekitar 70 persen (D. \& YA., wawancara mendalam, $24 \& 25$ Oktober, 2015). Dalam konteks keagamaan, masyarakat Desa Manislor menganut agama Islam - dan terbagi menjadi kedua kelompok: Jemaat Ahmadiyah dan Non-Jemaat Ahmadiyah.

Perkenalan penduduk Manislor dengan Ahmadiyah bermula dari hubungan baik antara E. Bening dan Soetardjo pada tahun 1953. Ketika itu, Bening menjabat sebagai Kepala Desa (Kuwu) Manislor sementara Soetardjo adalah seorang Ahmadi-atau sebutan untuk jemaat Ahmadiyah-yang menjabat sebagai Mantri Polisi di Kecamatan Jalaksana, Kuningan. Kedekatan hubungan mereka berdua membuat Soetardjo dapat leluasa memberikan informasi dan pengetahuan mengenai ajaran Ahmadiyah kepada Bening. Bagi Bening, apa yang disampaikan oleh Soetardjo bukan hal baru. Sebab, di kalangan orang-orang tua Manislor, keyakinan tentang akan datangnya 
Imam Mahdi atau Ratu Adil telah lama dipegang teguh (Prawira, 2012: 14-15).

Tidak lama kemudian, Bening akhirnya menerima ajakan Soetardjo untuk bergabung menjadi Jemaat Ahmadiyah. Di penghujung tahun 1953, Bening bersama keponakannya Soekrono yang ketika itu menjabat sebagia sekretaris Desa Manislor, dibaiat oleh $\mathrm{H}$. Basyari Hasan - seorang Mubaligh Ahmadiyah sekaligus Kepala Desa di Garut. Prosesi baiat ini dilangsungkan di Cirebon. Dari momen ini hingga tahun-tahun berikutnya, Basyari Hasan pindah kediaman ke Manislor atas permintaan Bening. Ada dua alasan yang menyebabkan Basyari Hasan pindah ke Manislor, yakni pertama, kampungya di Garut kerap mendapat gangguan dari kelompok Darul Islam atas alasan kontra Ahmadiyah; kedua, agar kemudian ia dapat membina dan mengajari para anggota Jemaat Ahmadiyah yang baru (akan) dibaiat.

Tepat pada Februari 1954, sebanyak 80 orang warga Manislor dibaiat dan menyatakan diri sebagai anggota Jemaat Ahmadiyah. Prosesi baiat ini berlangung berturut-turut dan hingga hari keempat, total warga Manislor yang dibaiat mencapai 391 orang. Hingga kini, jumlah anggota Jemaat Ahmadiyah di Manislor tidak kurang dari 70 persen dari total keseluruhan warga Manislor(Prawira, 2012: 16-21).

Perihal rumah ibadah, Desa Manislor memiliki total 9 bangunan rumah ibadah yang terbagi menjadi dua kepemilikan administratif: milik Jemaat Ahmadiyah dan milik Desa Manislor. Pertama, milik Jemaat Ahmadiyah: terdapat 7 bangunan musala dan 1 masjid. Kesemuanya memiliki fungsi yang sama sebagai rumah ibadah. Hanya saja masjid utama memiliki fungsi khusus lain, yaitu sebagai tempat pusat kegiatan keagamaan yang melibatkan seluruh Jemaat Ahmadiyah Desa Manislor, dan menjadi satu-satunya tempat pelaksanaan salat Jumat bagi Jemaat Ahmadiyah di Desa Manislor. Kedelapan rumah ibadah ini berdiri di atas tanah hibah warga Ahmadiyah setempat. Hal lain yang menarik, tidak seperti musala-musala pada umumnya yang bangun ruangnya lebih kecil, ketujuh musala di Desa ini memiliki bangun fisik yang besar dan bertingkat. Tidak heran, bila warga/masyarakat Non-Jemaat Ahmadiyah di Manislor-ataupun pihak luar/pendatang — kerap menyebutnya sebagai masjid, bukan musala. Kedua, milik Desa Manislor: 1 bangunan masjid. Masjid desa yang bernama al-Huda ini dulunya bernama Masjid Nur al-Huda, tempat seluruh warga Manislor melaksanakan ibadah salatnya. Namun sejak tahun 1954-satu tahun setelah masuknya paham Ahmadiyah di Desa Manislor, Jemaat Ahmadiyah setempat mendirikan masjid sendiri yang diberi nama Masjid an-Nur. Segala aktivitas ibadah warga Jemaat Ahmadiyah Manislor pun berpindah muara ke Masjid anNur. Sejak itu, masjid desa Nur al-Huda berubah nama menjadi Masjid al-Huda yang digunakan oleh seluruh warga Manislor non-Ahmadiyah (EJ., wawancara mendalam, 23 Oktober, 2015).

Perihal sektor pendidikan, dalam hal sarana di Desa Manislor terdapat masing-masing satu Sekolah Dasar, Sekolah Menengah Pertama, dan Madrasah Tsanawiyah; sedangkan terkait tingkat pendidikan masyarakat, mayoritas generasi muda di Desa Manislor melanjutkan pendidikan hingga ke perguruan tinggi umum dan akademi militer (Arsip Kesejarahan Desa Manislor \& YA., wawancara mendalam, 25 Oktober, 2015).

Jika kita mendalami pola permukiman, Desa Manislor secara sosiologis terbagi menjadi dua bagian: wetan/timur dan kulon/barat.Warga Jemaat Ahmadiyah lebih terkonsentrasi di bagian wetan, sedangkan warga Non-Jemaat Ahmadiyah sebagian besar terletak di bagian kulon desa (di sekitaran masjid desa, al-Huda). Meski demikian, tidak ada perbedaan kentara yang terlihat dari kondisi sosial ekonomi warga Jemaat Ahmadiyah dan Non-Jemaat Ahmadiyah. Produktivitas kerja masyarakat Desa Manislorterlepas dari kelompok - pada umumnya bertani atau buruh tani dan berdagang atau buruh dagang, dan sebagian kecil bekerja di sektor formal pemerintahan daerah dan pegawai negeri sipil (Arsip Kesejarahan Desa Manislor \& YA., wawancara mendalam, 25 Oktober, 2015). Dalam hal ini, interaksi dan jalin komunikasi kedua kelompok berlangsung harmonis.

Meski secara kasat mata tampak baikbaik saja, namun tidak bisa dipungkiri bahwa Manislor era reformasi adalah desa yang mana konflik mengemuka silih berganti, baik melibatkan pihak internal maupun eksternal desa. Konflik yang terjadi tidak hanya bermotifkan religius: memperjuangkan keyakinan beragamanya sembari menghancurkan keyakinan beragama lainnya, namun sudah menjadi rahasia umum bila ada motif politik, ekonomi, dan campur tangan pihak elit juga terlibat di 
dalamnya. Banyak pihak menyesalkan konflik yang terjadi selama ini, bukan saja karena menyangkut hak warga negara untuk memaknai keberagamaannya, namun juga secara sosiologis, sebetulnya masyarakat Kuningan sangat lekat dengan nilai-nilai asih, asah, dan asuh.

Konsep silih asah, silih asih, dan silih asuh merupakan prinsip hidup yang konon dianut oleh masyarakat Jawa Barat. Prinsip ini mengajarkan manusia untuk saling mengasuh dengan landasan saling mengasihi dan saling berbagi. Silih asah berarti harus saling memberi pengalaman dan pengetahuan, silih asih artinya harus saling mencintai, dan silih asuh artinya harus saling membimbing atau mengasuh (Suhamiharja, Suhandi, dkk., 1995: 29-31, 6970; Warnaen, 1988: 399-420). Dengan kata lain, masyarakat Sunda terkenal lebih mementingkan harmoni ketimbang konflik dan pertikaian. Ketiga sikap saling ini tentu diikuti dengan kesediaan saling memahami dan menghormati kendati berbeda agama dan keyakinan. Sikap saling dan norma timbal balik inilah yangsemestinya-menjadi salah satu unsur utama modal sosial, di samping sikap saling percaya/interpersonal trust dan jaringan kekerabatan/civic engangement (Putnam et al., 1993: 167), yang bisa mengeratkan sikap kewargaan masyarakat Manislor.

Tidak sedikit temuan di lapangan yang mencerminkan kesalingcurigaan antara kelompok warga dengan kelompok warga lainnya. Namun demikian, perasaan curiga tersebut hanya bekerja di ranah anggapan atau perasaan. Gambaran paling konkrit ada pada tataran masyarakat akar rumput/grass root: Kecurigaankecurigaan yang ada tidak lantas mempengaruhi aktivitas kewargaan masing-masing. Dalam kehidupan sehari-hari, warga Jemaat Ahmadiyah dan Non-Jemaat Ahmadiyah tetap menjalani komunikasi dengan baik dan normal layaknya kehidupan rukun bertetangga. Hal ini terlihat jelas dari ramah-tamah sederhana dan interaksiinteraksi mereka di ruang publik seperti warung, pasar, sawah, atau ketika sedang berpas-pasan di jalan. Perbedaan yang ada di antara mereka pada akhirnya dipahami masing-masing sebagai bagian dari kebebasan berkeyakinan yang sifatnya individual.

Secara praktis, masyarakat Jawa Barat memiliki banyak petuah lokal yang sejatinya berfungsi sebagai norma bagi pengelolaan konflik dan pembangunan harmoni. Seperti ungkapan "Herang caina beunang laukna" yang berarti menyelesaikan masalah tanpa menimbulkan masalah baru, atau yang lebih dimaknai dengan prinsip saling menguntungkan. Masyarakat Jawa Barat juga sedari luhur dikenal memiliki komitmen yang kuat terhadap nilai-nilai kebajikan seperti yang tersirat dalam petuah "Ulah unggut kalinduan, ulah gedeg kaanginan", yang berarti konsisten dan kensekuen terhadap nilai kebenaran dan keseimbangan antara hati nurani dan rasionalitas.

Pada mode relasi masyarakat akar rumput di Desa Manislor, prinsip-prinsip kesahajaan yang sudah turun-temurun tersebut hampir bisa dipastikan masih berkelindan dengan baik. Masyarakat Desa Manislor ketika sudah berada di ruang publik, baik Jemaat Ahmadiyah maupun Non-Jemaat Ahmadiyah, sudah dalam taraf mampu menjaga jarak dari kecurigaan atas perbedaan-perbedaan keyakinan beragama di antara mereka. Namun demikian, sejarah membuktikan bahwa menjaga agar persoalan tidak sampai muncul dalam suatu interaksi social memang bukan perkara mudah. Beberapa persoalan yang sifatnya antarpersonal dapat diselesaikan secara baik, namun lebar juga kemungkinan persoalan itu gagal ditangani.

Persoalan-persoalan yang gagal dikelola secara memadai akan sangat mungkin berkembang menjadi konflik. Keadaan pun semakin memburuk tatkala ketegangan antarpersonal tersebut berubah menjadi konflik komunal yang melibatkan massa dalam jumlah besar. Ada kala di mana nilai-nilai luhur yang sebelumnya dibangun melalui hubungan dialektika sosial kewargaanyang berfungsi sebagai perekat masyarakat, pada level tertentu tereduksi akibat tingginya sensitivitas dan fanatisme agama (Beckmann, 2009). Dari sini, sangat relevan rasanya bila nilai-nilai kearifan lokal lebih ditumbuhkembangkan menjadi bagian dari upaya resolusi konflik dan prakarsa perdamaian, tanpa harus bertabrakan dengan kaidah-kaidah Islam secara umumnya dan Ahmadiyah secara khsusnya. Apa lagi pada dirinya, individu-individu Manislor memiliki nilai perekat yang sudah tertanam bahkan sejak sebelum Islam menjajaki Tatar Sunda.

\section{Segregasi Sosial-Keagamaan Masyarakat Manislor}

Kita tentu bertanya-tanya, bagaimana Manislor yang kental dengan nilai-nilai 
kasundaan yang toleran justru mengalami pasang surut konflik dan kekerasan-perihal eksistensi Ahmadiyah, terlebih sejak reformasi menggema. Bukankah, reformasi-yang konon mampu memperbarui bangsa ini menjadi lebih manusiawi - telah berhasil menununjukkan prestasinya mewujudkan inti demokrasi: menjadikan kelompok mayoritas menjadi penguasa/majority rules. Atau jangan-jangan, masih ada yang tertinggal dari pencapaian tersebut, yakni proteksi terhadap kelompok minoritas/ protecting minority (Ropi, 2012; Ghanea, 2012; Barth, 2008). Kekhawatiran ini cukup beralasan jika melihat dinamika kasus kekerasan di Manislor dan daerah-daerah lainnya yang juga setipe. Artinya, ada ketidakseimbangan antara majority rules dan protecting minority yang kemudian memunculkan riak-riak konflik dan praktik-praktik dominasi.

Sementara itu, satu hal yang mesti kita sadari, dalam konteks Manislor definisi mayoritas-minoritas serta majority rules sendiri sejatinya kabur dan membingungkan. Jemaat Ahmadiyah yang terbilang mayor di Manislor (minoritas yang mayor), nyatanya tidak mampu untuk bilang tidak dari perlakuan dan kebijakan yang diskriminatif dan bersifat peminggiran. Tengok bagaimana peta kasus kekerasan/ ketegangan di Manislor selama ini, yang kasat mata terlihat adalah konsep "atas nama mayoritas" dibanding mayoritas itu sendiri. Dengan konsep "atas nama mayoritas", maka satu kelompok kecil yang dominan bisa dengan leluasa menghegemoni dengan berpayungkan mayoritas - yang sebenarnya plural.

Sepertinya tidak ada ungkapan yang lebih tepat untuk menyebut situasi relasional yang terbangun antara Jemaat Ahmadiyah dan Non-Jemaat Ahmadiyah di Manislor selain ungkapan "harmoni dalam kekacauan"/chaotic harmony-meminjam istilah Kingsley (2010). Penulis melihat masyarakat Manislor selama ini hidup dalam "satu garisantara": terkadang harmonis, terkadang berkonflik. Situasi yang sebenarnya membingungkan. Ada nilai-nilai kultur pengikat kewargaan yang menjadikan Manislor tetap dalam situasi kondusif dan tenang; namun di saat bersamaan ada kesadaran yang membuat Manislor selalu terjaga terhadap ketegangan dan kerusuhan yang siap meletus setiap saat. Situasi "antara"/in between ini terlihat dari pembagian permukiman yang jelas antara wetan dan kulon, namun batas-batas yang memisahkan wetan dan kulon itu sendiri sublim dan tidak tampak.

Pada level yang lebih kompleks, kemunculan segregasi sosial dalam tubuh Manislor dapat kita lihat dari faktor yang membentang: mulai dari motif teologis, politis, hingga sosio-ekonomis. Pada level tertentu, segregasi ini melahirkan kompetisi dan kontestasi dalam banyak hal. Sebut saja kontestasi pendirian rumah ibadah, lembaga pendidikan, organisasi kepemudaan, hingga tanah makam. Kontentasi yang berlangsung secara alamiah ini tentu pada satu sisi turut menyumbang energi positif bagi penguatan masing-masing kelompok. Namun pada lain sisi, seperti pernyataan Keith A. Roberts di awal tulisan ini, sulit bagi kedua kelompok menghindari munculnya persinggunganpersinggungan yang bermuara kepada konflik.

Jika dicermati secara seksama, berbagai konflik baik yang muncul di permukaan maupun yang tersembunyi/hidden conflict antara Jemaat Ahmdiyah dan Non-Jemaat Ahmadiyah di Desa Manislor, sejatinya melibatkan beberapa faktor:

\section{Akar Pemisahan Ruang}

Jemaat Ahmadiyah Indonesia secara organisasi resmi berdiri di Manislor pada tanggal 20 Februari 1956. Masuknya paham Ahmadiyah ke Manislor tidak lepas dari peran serta E. Bening, beserta dua orang saudaranya. Bening merupakan orang pertama Manislor yang dibaiat menjadi anggota Ahmadiyah. Bening yang kala itu menjabat sebagai Kepala Desa Manislor, serta-merta memiliki posisi strategis dalam menyebarkan ajaran Ahmadiyah. Pada hari pertama penyebaran, tercatat sekitar 80 jiwa mengajukan diri untuk dibaiat. Pada hari keempat setelahnya, jumlah penduduk Manislor yang dibaiat dan menyatakan diri sebagai anggota Jemaat Ahmadiyah sudah mencapai 391 jiwa. Perkembangan ajaran Ahmadiyah di Desa Manislor tergolong pesat, meski mendapat berbagai reaksi negatif dari masyarakat dan pemerintah (yang diwakili oleh Departemen Agama kala itu). Sejak mendapat banyak tentangan dari berbagai pihak, Jemaat Ahmadiyah Manislor pun mulai memisahkan diri dalam pelaksanaan ibadah salat; tidak lagi menggunakan masjid desa, namun beralih tempat di kediaman Bening (Arsip Kesejarahan Desa Manislor \& YA., wawancara mendalam, 25 Oktober, 2015). 
Segregasi ruang ini terus berlanjut dan berkembang. Hingga kini, Jemaat Ahmadiyah Manislor memiliki satu masjid utama/pusat dan tujuh musala yang dibangun di atas tanah wakaf dari pihak mereka sendiri. Selain rumah ibadah, Jemaat Ahmadiyah Manislor juga memiliki tanah perkuburan sendiri yang terpisah dari tanah perkuburandesa. Dulu, tanah perkuburan yang terhampar di atas tanah wakaf salah seorang Jemaat Ahmadiyah ini dinamakan Makam Surga atau Behisyti Maqbarah/ Perkuburan Ahli Surga(Ahmad, 2013: 3 \& 35;U.\& Y., wawancara mendalam, 23 Oktober, 2015). Merunut kepada penjelasan di dalam buku saku edaran JAI, Makam Surga merupakan perkuburan orang-orang Jemaat Ahmadiyah yang terpilih yang ahli surga. Tidak semua pihak Jemaat Ahmadiyah bisa dimakamkan di Makam Surga, kecuali orang-orang yang telah berwasiat atau berkomitmen dan membayar suatu jaminan dengan besaran tertentu. Namun karena menimbulkan reaksi yang kurang baik dari berbagai pihak di luar lingkaran Ahmadiyah, dan atas pertimbangan keamanan berasama, maka nama tanah Makam Surga pun dihapus (D.\& S., wawancara mendalam, 24 Oktober, 2015).

Secara masif, pemisahan ruang di Mansilor juga berimbas pada pemisahan permukiman-meski batas pemisah itu sendiri tidak kasat mata. Model permukiman yang tersegregasi secara paham keagamaan ini pada kondisi normal, bukan merupakan permasalahan sosial. Namun pada taraf tertentu, ada penggerusan nilai-nilai persaudaraan atau kewargaan. Sebagaimana warga Non-Jemaat Ahmadiyah menyebut "warga kulon" bagi pihak/individu Ahmadiyah, tidak peduli pihak/individu yang dimaksud masih memiliki hubungan kerabat dekat (A. \& D., wawancara mendalam, 24 Oktober, 2015).

\section{Akar Politik: Sentimen Kelompok, Masalah Identitas, dan Campur Tangan Elit}

Sudah menjadi rahasia umum bila momen-momen politik acapkali menjadi biang konflik dan ketegangan serta membuka lebar ruang berbagai kontestasi. Contoh paling konkrit adalah pemilihan kepala desa pada lanskap Manislor. Selama tujuh periode kepengurusan berturut-turut sejak tahun 1968 hingga sekarang, jabatan Kepala Desa Manislor selalu dimenangkan oleh orang-orang Ahmadiyah. Kepemimpinan oleh orang Ahmadiyah memang sudah terjadi sejak awal ajaran Ahmadiyah masuk ke Desa Manislorpada tahun 1954. Mengingat, ajaran Ahmadiyah masuk Manislor melalui E. Bening yang kala itu menjabat sebagai Kepala Desa Manislor sejak tahun 1949. Pemilihan kepala desa sejak masuknya Ahmadiyah ke Manislor baru dimulai lagi pada tahun 1968, dengan periode kepengurusan 19681979 yang dimenangkan oleh seorang warga Jemaat Ahmadiyah bernama Kulman Tisnaprawira.

Kenyataan inilah yang kemudian menimbulkan kecemburuan politis di dalam tubuh Manislor-lebih tepatnya pada tingkatan elit Non-Jemaat Ahmadiyah Manislor (YA., A., \& D., wawancara mendalam, 23 Oktober, 2015). Selalu dimenangkannya jabatan kepala desa oleh orang-orang dari kalangan Jemaat Ahmadiyah bisa dibilang wajar, mengingat jumlah Jemaat Ahmadiyah tidak kurang dari 3.000 jiwa terkonfirmasi dari sebanyak 4.616 jiwa penduduk Desa Manislor. Namun justru repetisi ini yang menjadi akar ketegangan dari pihak Non-Jemaat Ahmadiyah terhadap pihak Jemaat Ahmadiyah.

Begitu pula dengan kasus penangguhan KTP yang sudah sembilan tahun iniberlangsung bagi sebagian besar warga Jemaat Ahmadiyah Manislor (A. \& D., wawancara mendalam, 23 Oktober, 2015) semakin menegaskan problem identitas yang begitu politis. Meski pihak yang menjadi sasaran utama penangguhan adalah Jemaat Ahmadiyah, namun ada beberapa pula pihak Non-Jemaat Ahmadiyah Desa Manislor yang KTP-nya turut terkena dampak penangguhan. Penangguhan KTP bukan saja berimbas kepada hilangnya hak suara dalam pemilihan tingkat daerah, tetapi juga akan berimbas kepada hak-hak sosial Jemaat Ahmadiyah Manislor sebagai warga negara Indonesia. Maka kekhawatiran atas ketidakseimbangan antara majority rules dan protecting minority pun benar-benar beralasan: bermunculannya kebijakan/regulasi bernuansa diskriminatif baik pada level pusat maupun lokal. Salah satu contohnya adalah pernikahan warga JAI tidak dilayani di Kantor Urusan Agama (KUA) Kuningan dengan alasan JAI bukan Islam; pernikahan baru boleh dilakukan jika pihak pengaju membuat surat yang menyatakan diri keluar dari keanggotaan JAI dan kembali ke "Islam yang benar" (N., wawancara mendalam, 24 Oktober, 2015). Tampak benar adanya, bahwa identitas hadir 
bukan sebagai sesuatu yang ada pada dirinya/nature, melainkan hadir dan menjelma menjadi wilayah kontestasi dan konstruksi yang ada pada kondisi-kondisi tertentu,serta dapat dinegosiasi demi tujuan-tujuan politis.

Sejatinya, kebijakan-kebijakan tersebut tidak benar-benar bijak dalam mencegah konflik. Sebaliknya, ia justru menimbulkan kerancuan dan seringkali menjadi alat justifikasi atas aksi-aksi intoleransi. Bahwasanya dalam perspektif pemerintah, untuk menciptakan situasi yang kondusif dan tenang, maka harus ada yang dielus tetapi juga ditekan. Dalam konteks Manislor, Jemaat Ahmadiyah adalah kelompok yang paling bisa diam dan tenanguntuk tidak mengatakan pasrah-ketimbang kelompok masyarakat Non-Jemaat Ahmadiyah (MS., wawancara mendalam, 24 Oktober, 2015).

\section{Akar Sosio-Ekonomi}

Tidak begitu jelas disparitas ekonomi yang tampak ketika kita memasuki jalan beraspal Desa Manislor. Sekilas tampak bahwa sebagian besar bangunan-bangunan rumah di desa ini terbilang memenuhi prasyarat layak huni. Terlebih jika kita menelusuri lebih dalam ke arah barat/kulon, tempat sebagian besar warga Jemaat Ahmadiyah Manislor bermukim. Meski merupakan permukiman padat penduduk, bangunan-bangunan rumah di permukiman ini masih terlihat rapi dan mapan bahkan hingga ke gang-gang terkecil.Namun demikian, masih terdapat sepuluh rumah berkategori tidak layak huni yang kesemuanya adalah milik warga NonJemaat Ahmadiyah. Baik sektor ekonomi warga Jemaat Ahmadiyah maupun Non-Jemaat Ahmadiyah, sama-sama berumber pada sektor pertanian dan perdagangan, dan sebagian kecil wiraswasta dan pegawai negeri sipil (YA., wawancara mendalam, 25 Oktober, 2015).

Tidak mudah bagi penulis untuk menemukan keterkaitan langsung antara munculnya konflik dengan kecemburuan ekonomi di Manislor. Setidaknya, tidak jika hanya mengandalkan visi bangunan secara fisik. Diperlukan faktor lain seperti pemicu/trigger dan escalating factor yang meluapkan ketegangan menjadi konflik terbuka. Dari beberapa dialog dan diskusi penulis dengan banyak pihak baik Jemaat Ahmadiyah maupun Non-Jemaat Ahmadiyah, tersirat bahwa salah satu unsur pemicu konflik adalah rasa curiga yang dialamatkan kepada warga Jemaat
Ahmadiyah. Kondisi ekonomi Jemaat Ahmadiyah Manislor yang sebagian besar menempati posisi kelas menengah atas, dinilai sebelah oleh sebagian pihak dan kalangan elit Non-Jemaat Ahmadiyah karenaselalu mendapat bantuan dana dari pemerintah Inggris (A. \& S., wawancara mendalam, $23 \& 24$ Oktober, 2015). "Kalau konflik, [s]udah dari tahun '84. Kebanyakan dari pendatang. Tapi kalo dari orang sini asli ya sebetulnya konfliknya ya karena cemburu sosial yang bukan Ahmadi ke yang Ahmadi [s]aja." (D., wawancara mendalam, 23 Oktober 2015). Secara sosial, warga Jemaat Ahmadiyah memang termasuk ke dalam kelas sosial menengah ke atas. Sementara warga NonJemaat Ahmadiyah memiliki kelas sosial yang bervariatif. Kesenjangan semacam ini yang menjadi salah satu pemantik renggangnya hubungan sosial antara mereka namun tidak sampai kepada ketegangan fisik.

\section{Habituasi Gotong-Royong sebagai Mekanisme Pelebur Segregasi}

\begin{abstract}
"Sebetulnya kalo di akar rumput, terus terang tidak ada masalah. Petaninya bisa macul di ladang yang sama, pemudanya bisa main bola di lapangan yang sama. Cuman di level elit ini yang agak sulit baik di kalangan jemaat ahmadiyah maupun yang bukan jemaat ahmadiyah. Seolah-olah di sini ada sekat yang emang sulit ditembus. Makanya saya tidak mungkin mengadakan suatu acara yang mempertemukan pemukapemuka Ahmadiyah dan yang bukan ahmadiyah. Karena tidak mungkin dan pasti tidak akan ada hasil. Bahkan mungkin akan lebih cenderung yang kalo kata orang Sundanya, ngahudangkeun macan turu [membangunkan macan tidur, penj.]. Makanya saya lebih cenderung membuat kegiatan yang mereka semua sama-sama hadir. Tapi untuk kegiatan-kegiatan lokal atau tradisi seperti nitip waktu bangun rumah, macul di sawah, ya semuanya aman dan rukun-rukun saja." (YA., wawancara mendalam, 25 Oktober, 2015).
\end{abstract}

Dalam habituasi masyarakat Manislor, konsep gotong-royong masih terasa kental dan melekat di beberapa aktivitas kewargaan. Salah satu pola gotong-royong yang keberlangsungannya melampaui batas segregasi antara Jemaat Ahmadiyah dan Non-Jemaat Ahmadiyah adalah tradisi nitip. Tradisi nitip merupakan bentuk kerja sama menitipkan sejumlah material untuk pihak yang berhajat membangun rumah. Mekanisme kerjanya: ketika salah satu warga 
bermaksud membangun rumah, maka ia membentuk semacam riungan/grup/perkumpulan untuk mengabarkan perihal niatan membangun rumah. Riungan ini dimaksudkan untuk mengundang sekaligus menarik pihak-pihak yang bersedia gotong-royong menitipkan material-material tertentu untuk kelancaran proses pembangunan rumah. Kemudian, pihak yang bersedia pun mulai nitip/menitipkan material-material seperti kayu, batu, pasir, semen, genteng, atau bahan-bahan lainnya yang dibutuhkan dalam proses pembangunan rumah. Tidak ada aturan baku mengenai besaran jumlah material yang dititipkan, semuanya bergantung pada kesediaan dan ketersediaan pihak penitip. Di waktu yang akan datang, jika pihak penitip berganti hendak membangun rumah (entah rumah untuk anak, saudara, atau kerabat tanggungannya), maka warga yang dulu pernah dititipkan beralih wajib mengembalikan titipan, dengan besaran materi yang setara dengan yang pernah ia dapatkan ketika membangun rumah

Secara esensi, tradisi nitip bersifat mengikat. Mereka yang terlibat di dalamnya, terikat dengan komitmen dan kepercayaan yang tinggi/interpersonal trust (Anheier \& Kendall, 2002; Boggs, 2016; Boix \& Posner, 1998; Putnam et al., 1993: 67). Beberapa kesan yang penulis dapat, tradisi nitip efektif dalam mengubur perasaan curiga/prejudice dan stereotip antarkelompok. Tradisi yang sudah berlangsung puluhan generasi ini sejatinya untuk meringankan beban tetangga, kerabat, atau anggota masyarakat di lingkungan sekitar. Selayaknya asuransi sosial dalam bentuk yang sederhana, penulis menemukan fakta bahwa tradisi nitip ini mampu langgeng-bahkan dalam kehidupan masyarakat Manislor yang penuh dinamika konflik dan ketegangankarena nilai dan jaminan sosial yang dikandungnya.

Bentuk gotong-royong lain yang dapat meleburkan batas-batas segregasi secara nyata adalah aktivitas bertani. Pada satu petak sawah yang sama, kita akan mendapati para tuan tani dalam relasi yang harmonis tanpa label Ahmadiyah maupun Non-Ahmadiyah. Bahkan, beberapa informan menyatakan bahwa walaupun di malam hari Manislor berkonflik, namun tidak jika sedang di sawah siang harinya. Para tuan tani baik dari Jemaat Ahmadiyah maupun Non-Jemaat Ahmadiyah, tetap akur dan berinteraksi seperti biasa laiknya sesama penggarap sawah. (T., \& YA., wawancara mendalam, 25 Oktober 2015). Interaksi yang sehat antara kedua kelompok masyarakat ini ketika di sawah, terbukti mampu meredam berbagai stereotip dan rumor negatif yang acapkali berkembang di masyarakat Manislor.

\section{Penutup}

\section{Harmoni itu masih ada (?)}

Manislor adalah satu dari sekian banyak permukiman yang bergejolak dalam kesunyian. Terkadang ia berkonflik, terkadang ia berdamai. Hidup dalam "satu garis antara" bukan hal yang penulis yakini mudah untuk dilalui masyarakatnya. Namun demikian, penelitian ini akhirnya mengantarkan penulis pada realitasrealitas sunyi yang jarang diumbar. Kohesi sosial masyarakat Manislor nyatanya dibangun dan dipelihara melalui serangkaian ikatan antarwarga yang sifatnya mengalir/quotidian. Ada kepercayaan/trust dan resiprositas/ reciprocity yang masih tertinggal, yang pada level-level tertentu justru semakin menguatkan jalin relasi antarkelompok, antara Jemaat Ahmadiyah dan Non-Jemaat Ahmadiyah. Tradisi nitip dan bertani adalah dua pengikat/ social bonding sekaligus jembatan/social bridging yang tanpa sadar menumbuh kembangkan harmoni kedua kelompok Manislor. Tentu, dengan penggalian lebih dalam, pasti ada kendaraankendaraan pengikat damai lainnya.

Adapun persoalan segregasi, penulis ingin menyepakati bahwa teologis bukan lagi faktor tunggal munculnya konflik dan intoleransi di Manislor. Teologis di sini hanya manifestasi komunalisme yang berkelindan dengan persoalanpersoalan sosial lainnya: pemisahan ruang, sentimen kelompok, persoalan identitas, campur tangan elit, hingga sosio-ekonomi. Untuk itu, penguatan ikatan kewargaan seperti habituasihabituasi lokal dalam resolusi konflik dan upaya membangun bina-damai nir-kekerasan merupakan satu hal yang urgent. Begitu pula agen-agen civil society yang dengan caranya masingmasing, harus sedia dan peduli mengawal mekanisme penanganan konflik. Kemudian pemerintah, sebisa mungkin peka untuk selalu mengkonsolidasikan semua potensi masyarakat demi kehidupan bernegara yang lebih berkelanjutan.

Ibu kota, di mana damai berkelin dan sunyi. Salam. 


\section{Daftar Pustaka}

Adams, C.J. (1985). The Hermeneutics of Henry Corbin. In R.C. Martin (Ed.), Approaches to Islam in Religious Studies (hal. 129-150). Arizona: The University of Arizona Press.

Ahmad, M.G. (2013). Al-Wasiat. Bogor: Jemaat Ahmadiyah Indonesia.

Amstrong, K. (2013). Compassion: 12 Langkah Menuju Hidup Berbelas Kasih. Bandung: Mizan.

Anheier, H., \& Kendall, J. (2002). Interpersonal Trust and Voluntary Associations: Examining Three Approaches. The British Journal of Sociology, 53(3), 343-362. https://doi.org/10.1080/0007 131022000000545

Badan Pusat Statistik Kabupaten Kuningan. (2016). Statistik Daerah Kecamatan Jalaksana 2016. Kuningan, Jawa Barat. Diambil dari http://kuningankab.bps.go. id

Barker, C. (2004). The SAGE Dictionary of Cultural Studies (Digital). London: SAGE Publications. Diambil dari http://ww1.bookzz.org/book/609392/d7 4478

Barth, W.K. (2008). On Cultural Rights: The Equality of Nations and the Minority Legal Tradition. Leiden: Martinus Nijhoff Publishers. Diambil dari http://ww1.bookzz.org/book/1215858/0 0a9af

Beckmann, F. von B. (2009). Riding or killing the centaur? Reflections on the Identities of Legal Anthropology. International Journal of Law in Context, 4(2), 85-110. https://doi.org/http:// dx. doi.org/10.1093/acprof:oso/9780199580 910.003.0001

Bertrand, J. (2007). Nationalism and Ethnic Conflict in Indonesia (Digital Pr). New York: Cambridge University Press. Diambil dari www.cambridge.org/ 9780521818896

Boggs, C. (2016). Social Capital and Political Fantasy: Robert Putnam $\hat{a} €^{\mathrm{TM}} \mathrm{s}$ "Bowling Alone." Theory and Society, 30(2), 281-297. Diambil dari http://www.jstor.org/stable/657878
Boix, C., \& Posner, D.N. (1998). Social Capital: Explaining Its Origins and Effects on Government Performance. British Journal of Political Science, 28(4), 686-693. Diambil dari https://www.cambridge.org/core/article/ social-capital-explaining-its-originsand-effects-on-governmentperformance/4C8342C37321E86610E8 DA85F464B298

Bourdieu, P., \& Wacquant, L.J.D. (1992). An Invitation to Reflexive Sociology (1st Editio). Chicago: University of Chicago Press. Diambil dari http://ww1.bookzz. org/book/917884/8befe0

Colbran, N. (2016). Realities and challenges in realising freedom of religion or belief in Indonesia, 2987(November), 678-704. https://doi.org/10.1080/1364298090315 5166

Colemen, J.S. (1990). Foundation of Social Theory. Cambridge M.A.: Hardvard University Press.

Erricker, C. (2002). Pendekatan Fenomenologis. In P. Connolly (Ed.), Aneka Pendekatan Studi Islam (hal. 105-146). Yogyakarta: LKiS.

Fisher, S., Ludin, J., Williams, S., Williams, S., Abdi, D.I., \& Smith, R. (2000). Working with Conflict: Skills and Strategies for Action. New York: Zed Books.

Ghanea, N. (2012). Are Religious Minorities Really Minorities? Oxford Journal of Law and Religion, 1(1), 57-79. https://doi.org/10.1093/ojlr/rwr029

Institute for Economics \& Peace. (2014). Global Peace Index 2014; Measuring Peace and Assessing Country Risk. Sydney. Diambil dari http://www.economicsand peace.com

King, U. (1995). Historical and Phenomenological Approaches. In F. Whaling (Ed.), Theory and Method in Religious Studies: Contemporary Approaches to the Study of Religion (hal. 41-176). Berlin; New York: Mouton de Gruyter.

Kingsley, J.J. (2010). Tuan Guru, community and conflict in Lombok, Indonesia. University of Melbourne. Diambil dari http://hdl.handle.net/11343/35693 
Kymlicka, W. (2001). Politics in the Vernacular: Nationalism, Multiculturalism and Citizenship. London: Oxford University Press.

Making Democracy Work, Civic Relation in Indonesia's New Order. (n.d.).

Maso'ed, M., \& Maksum, M. (2000). Kekerasan Kolektif, Kondisi, dan Pemicu. Yogyakarta: P3PK UGM.

Mclaughlin, K., \& Perdana, A. (2010). Conflict and Dispute Resolution in Indonesia Information from the 2006 Governance and Decentralization Survey (Indonesian Social Development Paper; 16 No. 53716). Washington, DC. Diambil dari http://documents.worldbank.org/curated /en/492901468040487843/Conflict-anddispute-resolution-in-Indonesiainformation-from-the-2006-governanceand-decentralization-survey

Miles, M.B., Huberman, A.M., \& Saldana, J. (2014). Qualitative Data Analysis: An expanded Sourcebook (3rd Editio). California: SAGE Publications.

Mujiburrahman. (2006). Feeling Threatened: Muslim-Christian Relations in Indonesia's New Order (ISIM Disse). Amsterdam: Amsterdam University Press. Diambil dari http://dspace.library.uu.nl/bitstream/ handle/1874/12667/full.pdf?sequence $=13$

Patulny, R.V, Lind, G., \& Svendsen, H. (2007). Exploring the Social Capital Grid: Bonding, Bridging, Qualitative, Quantitative. The International Journal of Sociology and Social Policy, 27(1/2), 32-51. https://doi.org/10.1108/014433307107 22742

Prawira, T. (2012). Sejarah Desa Manislor \& Sejarah Jemaat Ahmadiyah Cabang Manislor. Kuningan, Jawa Barat.

Putnam, R.D., Leonardi, R., \& Nanetti, R.Y. (1993). Making Democracy Work: Civic Traditions in Modern Italy (STU-Stud). Princeton: Princeton University Press. Diambil dari http://www.jstor.org/ stable/j.ctt7s8r7

Roberts, K.A. (2004). Religion in Sociological Perspective. Belmont: Wadsworth.

Ropi, I. (2012). Minoritas, Legal Jihad, dan Peran Negara. Jurnal Maarif: Negara,
Agama, dan Perlindungan Hak-hak Minoritas, 7(1), 12-26.

SETARA Institute. (2016). Bahan Bacaan Indeks HAM 2015. Jakarta. Diambil dari http://setara-institute.org/wpcontent/uploads/2016/01/BAHANBACAAN-INDEKS-HAM-2015.pdf

SETARA Institute. (2017). Kondisi Kebebasan Beragama di Indonesia 2016. Jakarta. Diambil dari http://setara-institute.org/ kondisi-kebebasanberagamaberkeyakinan-dan-minoritaskeagamaan-di-indonesia-2016/

Suhamiharja, Suhandi, A., \& dkk. (1995). Wujud Arti dan Fungsi Puncak-puncak Kebudayaan Lama dan Asli bagi Masyarakat Pendukungnya di Jawa Barat. Bandung: Direktorat Sejarah dan Nilai Tradisional.

The Wahid Institute. (2014). Laporan Tahunan Kebebasan Beragama/Berkeyakinan dan Intoleransi 2014. Jakarta.

Vandenberghe, F. (2006). The Age of Epigones: Post-Bourdieusian Social Theory in France. In G. Delanty (Ed.), Handbook of Contemporary European (Digital, hal. 69-81). New York: Routledge. Diambil dari http://ww1.bookzz.org/ book/733154/83a6c3

Vendley, W., \& dkk. (2011). Merayakan Kebebasan Beragama. In E.P. Taher (Ed.), Bunga Rampai 70 Tahun Djohan Effendi (hal. 698-702). Jakarta: Democracy Project. Diambil dari www.abad-demokrasi.com

Warnaen, S. (1988). Pandangan Hidup Orang Sunda: Satu Hasil Studi Awal. In H.W. Bachtiar (Ed.), Masyarakat dan Kebudayaan: Kumpulan karangan untuk Prof. Dr. Selo Soemardjan (hal. 399-420). Jakarta: Djambatan.

\section{Rujukan Wawancara}

Asep, Warga Masnislor Non-Ahmadiyah, Pengurus Rukun Warga.

Dimayati (52 tahun), Warga Masnislor, Anggota Jemaat Ahmadiyah, Petani.

Jamhari (80 tahun), Warga Manislor, Anggota Jemaat Ahmadiyah, Sesepuh Desa. 
Muhammad Syafaat, Pengurus Komite Nasional Pemuda Indonesia (KNPI) Cirebon.

Nursali, Warga Manislor, Anggota Jemaat Ahmadiyah.

Salimin Sa'dillah (61 tahun), Pengurus MUI Kabupaten Kuningan 1983-sekarang.

Tohari (77 tahun), Warga Manislor, Anggota Jemaat Ahmadiyah.

Uun (53 tahun), Warga Manislor, Anggota Jemaat Ahmadiyah, Ibu Rumah Tangga, Pedagang.

Yati (28 tahun), Warga Manislor, Anggota Jemaat Ahmadiyah, Ibu Rumah Tangga, Pedagang.

Yusup Ahmadi, Kepala Desa Manislor periode 2007-sekarang. 